\title{
First report of leaf spot caused by Colletotrichum siamense on Sophora tonkinensis
}

\author{
L. S. Song ${ }^{1}$ - N. Jiang ${ }^{1} \cdot$ Q. P. Chen ${ }^{1} \cdot$ S. X. Feng ${ }^{1} \cdot$ Z. J. Zhang ${ }^{1}$
}

Received: 3 May 2020 / Accepted: 1 February 2021 / Published online: 9 April 2021

(c) Australasian Plant Pathology Society Inc. 2021

\begin{abstract}
A leaf spot, found on Sophora tonkinensis in Hechi city, Guangxi province, China was identified as Colletotrichum siamense based on morphological and molecular phylogenetic analysis of the internal transcribed spacer (ITS) of ribosomal DNA, $\beta$-tublin (TUB2), the translation elongation factor 1-alpha (TEF1- $\alpha$ ), glyceraldehyde-3-phosphate dehydrogenase (GAPDH), actin (ACT), chitin synthase 1 (CHS-1), calmodulin (CAL) and glutamine synthetase (GS) genes. Koch's postulates were satisfied by successful reisolation of $C$. siamense only from plants inoculated with the pathogen. This is the first report of leaf spot caused by C. siamense on Sophora tonkinensis.
\end{abstract}

Keyword Sophora tonkinensis $\cdot$ Colletotrichum siamense $\cdot$ leaf spot

Sophora tonkinensis (Fabaceae) is known as Shān dòu gēn ("Mountain bean root") and is a well known leguminous medicinal plant in China. It grows in the tropical zone of Guangxi, Guangdong and Yunnan provinces in southern China (Wang et al. 2011). In May 2018, severe leaf spot symptoms were observed on 30-40\% of S. tonkinensis plants growing in commercial plantations at Hechi city, Guangxi province, China.

On infected leaves there were circular brown spots, 1-2 $\mathrm{mm}$ in diameter, reaching 3-5 $\mathrm{mm}$ in diameter after 8 days. These leaves gradually changed from green to yellow before defoliating. The infected leaves were surfacesterilised in $75 \%$ ethanol for $30 \mathrm{~s}$ then in $2 \%$ sodium hypochlorite for $3 \mathrm{~min}$, and finally $75 \%$ ethanol for $30 \mathrm{~s}$. Then samples were rinsed three times with sterile water, dried on sterile filter paper, cut into small pieces and placed on potato dextrose agar (PDA) in $9 \mathrm{~cm}$-diameter petri dishes which were incubated in an incubator at $28{ }^{\circ} \mathrm{C}$ under a $12 \mathrm{~h}$ light $/ 12 \mathrm{~h}$ dark cycle.

Twenty-seven of the resulting 30 fungal isolates showed similar morphological characteristics. A single-spore

N. Jiang

jiangni292@126.com

L. S. Song

lishasong@126.com

1 Guangxi Botanical Garden of Medicinal Plants, Nanning 530023, Guangxi, China isolate, s-8-2, was selected as representative for molecular identification, and deposited as ACCC 39,685 in Agricultural Culture Collection of China. Colonies of ACCC 39,685 grown on PDA for up to 15 days at $28{ }^{\circ} \mathrm{C}$ were initially light grey and later becoming darker, with cottony mycelium. Acervuli became evident initially at the centre of 10-day-old colonies, then developed radially outward from that point. Conidia produced in orange acevuloid masses were straight, aseptate, cylindrical, with obtuse apices and were 10-(15)$20 \times 3-(4)-5 \mu m(n=50)$. Based on these morphological characteristics, those isolates correspond to the asexual morphs of species belonging to C. gloeosporioides complex (Cannon et 1al. 2012; Weir et al. 2012; Hyde et al. 2009; Photita et al. 2005; Wang et al. 2016).

The single-spore isolate ACCC 39,685 was used to make a molecular identification (Fig. 1). For precise identification of the fungus, genomic DNA of ACCC 39,685 was extracted from the mycelium of a 7-day-old colony growing on PDA at $25^{\circ} \mathrm{C}$ using a MightyAmp DNA Polymerase Ver.3 (1.25 U/50 $\mu \mathrm{l}$ ) (Takara Bio, Kusatsu, Japan R076A) kit following the manufacturer's instructions. The internal transcribed spacer (ITS) of ribosomal DNA (White et al. 1990), $\beta$-tubulin (Weir et al. 2012), the translation elongation factor 1-alpha (EF-1 $\alpha)$ (Carbone and Kohn 1999), glyceraldehyde -3-phosphate dehydrogenase (Weir et al. 2012), actin (ACT) (Weir et al. 2012), chitin synthase 1 (CHS-1) (Weir et al. 2012), calmodulin (CAL) (Weir et al. 2012) and glutamine synthetase (GS) (Stephenson et al. 1997) genes were 


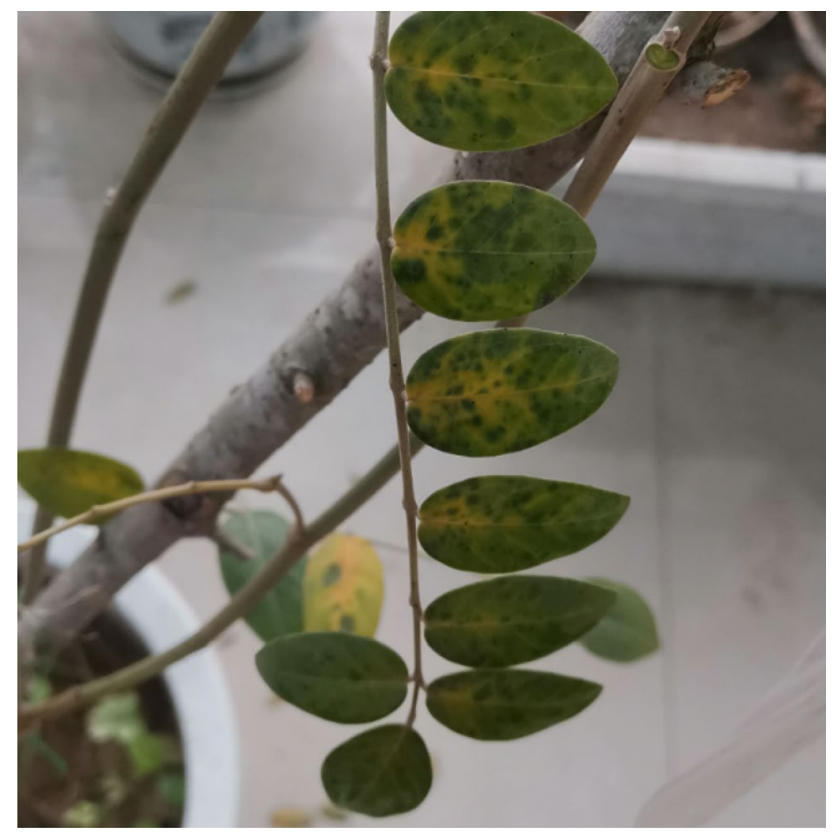

Fig. 1 Symptoms on leaves 8 days after inoculation with a conidium suspension of isolate ACCC 39,685

amplified with the eight primer pairs. The ITS, $\beta$-tublin, TEF1- $\alpha$, GADPH, actin, CHS-1, CAL and GS sequences, which were deposited in the GenBank database (accession numbers MK371784, MK976658, MK350298, MK952143, MK976660, MK976659, MT263723, MT263724, respectively). A BLAST search of GenBank showed that ITS and EF- $1 \alpha$ were $100 \%$ identical to $C$. gloeosporioides, respectively, but, the other six sequences of the strain ACCC 39,685 were $99 \%$ identified as $C$. siamense. The multilocus analysis (Mo et al. 2018) carried out with 14 other isolates of Colletotrichum revealed that ACCC 39,685 was a $100 \%$ match with isolate ICMP 18,578 , the type of $C$. siamense (Fig. 2). Based on morphology and molecular results, isolate ACCC 39,685 was identified as $C$. siamense.

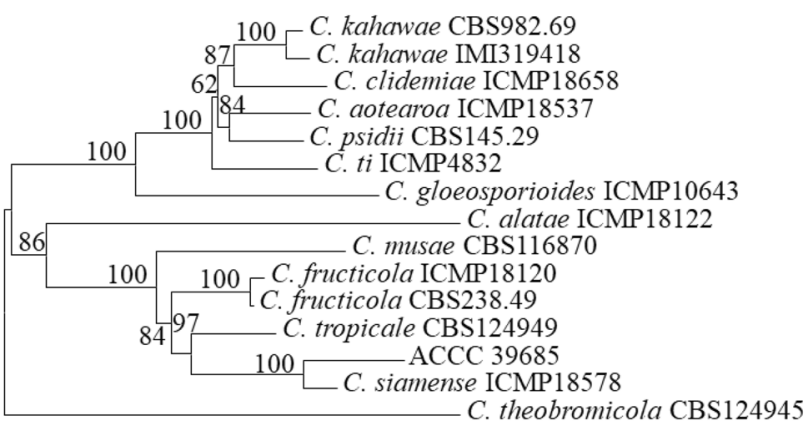

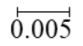

Fig. 3 Maximum Parsinomy phylogenetic tree using combined ITS, $\beta$-tubulin, TEF 1- $\alpha$, glyceraldehyde-3-phosphate dehydrogenase, ACT, CS-1, CAL and GS genes. Bootstrap values $>50 \%(1,000$ replication) are given at the nodes. Colletotrichum theobromicola CBS124945 was used as the outgroup isolate. NOTE: CBS: CBSKNAW, Fungal Biodiversity Center, Utrecht, the Netherlands. ICMP: International Collection of Microorganisms from Plant, Landcare Research, Auckland, New Zealand

Eight leaves on each of two healthy 3-year-old trees of $S$. tonkinensis growing in non-sterile soil in $13.4 \mathrm{~L}$ pots were surface-sterilized with $75 \%$ ethanol, rinsed in sterile water, then spray-inoculated with $20 \mu \mathrm{L}$ per leaf of an aqueous conidium suspension $\left(1 \times 10^{6}\right.$ conidia/mL $)$. Eight leaves on a control plant were surface-sterilized with $75 \%$ ethanol, rinsed with sterile water afterwards, then sprayed with $20 \mu \mathrm{L}$ of sterilized water. All plants were covered with a plastic bag for $48 \mathrm{~h}$ to maintain high humidity. After 8 days incubation at $28{ }^{\circ} \mathrm{C}$ and $90 \%$ relative humidity in a greenhouse, the area around the inoculation site had symptoms that were identical to those initially observed, whereas the control leaves on healthy seedlings inoculated with sterile water free remained symptomless. The pathogen $C$. siamense was reisolated from the lesions, fulfilling Koch's postulates (Fig. 3). The same pathogenicity assay was performed twice, with the same results.
Fig. 2 Morphological characteristics of a Colletotrichum siamense colony (isolate ACCC $39,685)(\mathrm{A})$ and microconidia (B) on potato dextrose agar after incubation for 7 days at $25^{\circ} \mathrm{C}$ and a $12 \mathrm{~h}$ light/ $12 \mathrm{~h}$ dark regime
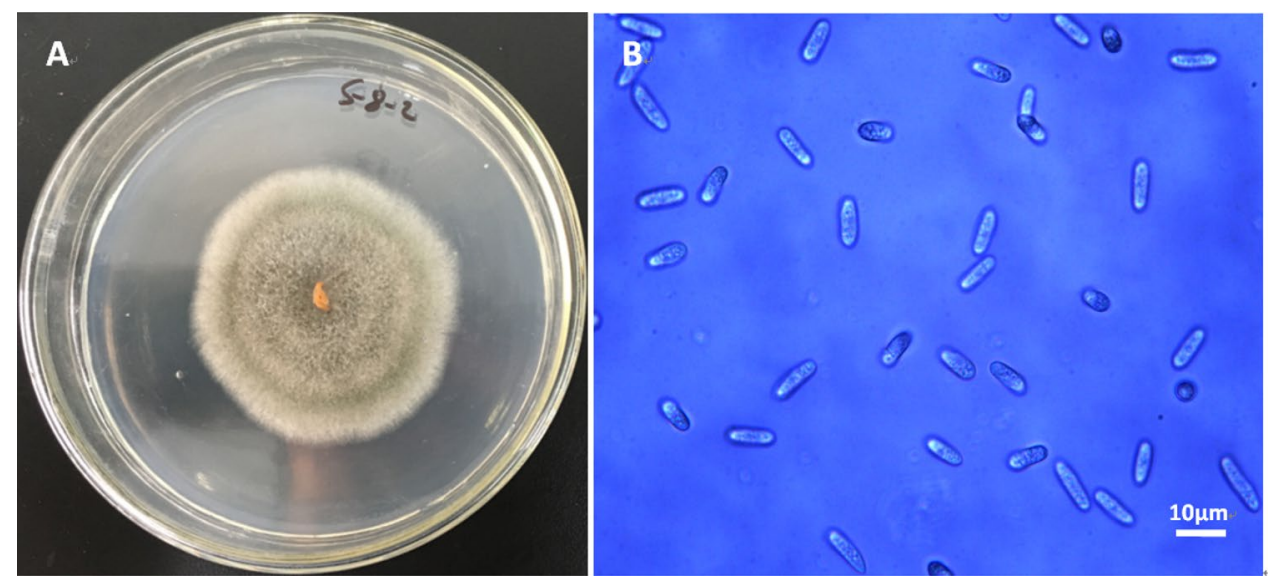
The pathogen responsible for leaf spot on S. tonkinensis in China has been identified in this study as $C$. siamense based on morphological and molecular studies. Colletotrichum siamense can infect more than 60 species of plants worldwide (Ji et al. 2019), but there have been no previous reports of the pathogen on S. tonkinensis. In China, various diseases caused by $C$. siamense can infect other hosts include Sterculia nobilis (Zhang et al. 2020a, b), Sterculia lanceolata (Zhang et al. 2020a, b), Hevea brasiliensis (rubber tree) (Cao et al. 2019), Mallotus oblongifolius (Partridge tea) (Liu et al. 2018), Macadamia sp. (Qiu et al. 2020), Litchi chinensis (Ling et al. 2019), and Camellia sinensis (Wang et al. 2016). Although there have been other reports of Colletotrichum species on S. tonkinensis, namely C. gloeosporioides (Shivas and Alcorn 1996) and C. simmondsii (as an endophyte from roots) (Yao et al. 2017), ours is the first known record of $C$. siamense on the plant of $S$. tonkinensis.

Acknowledgements This study was supported by the Special Fund for Innovation-driven Development in Guangxi, P. R. China (AA17204056-4), and the Guangxi Science and Technology Base and Talent Special Project (Gui ke AD16380013), Guangxi science and technology plan project (Gui ke AD17292004), Organic medicine cultivation and evaluation research team, (Gui yao chuang 2019007), Youth Science Fundation of Guangxi Botanical Garden of Medicinal Plants (Gui yao ji 201801).

\section{References}

Cannon PF, Damm U, Johnston PR, Weir BS (2012) Colletotrichum - current status and future directions. Stud Mycol 73:181-213

Cao X, Xu X, Che H, West JS, Luo D (2019) Three Colletotrichum species, including a new species, are associated to leaf anthracnose of rubber tree in Hainan. China Plant Dis 103:117-124

Carbone I, Kohn LM (1999) A method for designing primer sets for speciation studies in filamentous ascomycetes. Mycologia 91:553556. https://doi.org/10.2307/3761358

Hyde KD, Cai L, Cannon PF, Crouch JA, Crous PW, Damm U, Goodwin PH, Chen H, Johnston PR, Jones EBG, Liu ZY, McKenzie EHC, Moriwaki J, Noireung P, Pennycook SR, Pfenning LH, Prihastuti H, Sato T, Shivas RG, Tan YP, Taylor PWJ, Weir BS, Yang YL, Zhang JZ (2009) Colletotrichum names in current use. Fungal Divers 39:147-182

Ji J, Wang T, Xu X, Wang XY, Wu QQ, Li WY, Yao LG (2019) First report of Colletotrichum siamense causing leaf spot on redbud in China. Plant Dis 103:585

Ling JF, Song XB, Xi PG, Cheng BP, Cui YP, Chen X, Zhang LH (2019) Identification of Colletotrichum siamense causing litchi pepper spot disease in mainland China. Plant Pathol 68:1533-1542
Liu T, Chen D, Liu Z, Hou JM (2018) First report of Colletotrichum siamense causing anthracnose on partridge tea (Mallotus oblongifolius) in China. Plant Dis 102:1669. https://doi.org/10. 1094/PDIS-12-17-1957-PDN

Mo JY, Zhao G, Li QL, Solangi GS, Tang LH, Guo TX, Huang SP (2018) Identification and characterization of Colletotrichum species associated with mango anthracnose in Guangxi, China. Plant Dis 102:1283-1289. https://doi.org/10.1094/ PDIS-17-1516-RE

Photita W, Taylor PWJ, Ford R, Lumyong P, McKenzie EHC, Hyde KD (2005) Morphological and molecular characterization of Colletotrichum species from herbaceous plants in Thailand. Fungal Divers 18:117-133

Qiu F, Xu G, Xie CP, Li X, Zheng FQ, Wang WL (2020) First report of Colletotrichum siamense causing macadamia anthracnose in China. Plant Dis, first look. https://doi.org/10.1094/ PDIS-05-20-0994-PDN

Shivas RG, Alcorn JL (1996) A checklist of plant pathogenic and other microfungi in the rainforests of the wet tropics of northern Queensland. Australasian Plant Pathol 25:158-173

Stephenson SA, Green JR, Manners JM, Maclean DJ (1997) Cloning and characterization of glutamine synthetase from Colletotrichum gloeosporioides and demonstration of elevated expression during pathogenesis on Stylosanthes guianensis. Curr Genet 31:447-454

Wang JK, Xie XF, Fan CY, Liu M (2011) Sophorae tonkinensis radix et rhizoma. In: Peng C (ed) Chinese Geoherbs. China Press of Traditional Chinese Medicine, Bei Jing, pp 3305-3320

Wang YC, Hao XY, Wang L, Xiao B, Wang XC, Yang YJ (2016) Diverse Colletotrichum species cause anthracnose of tea plants (Camellia sinensis. (L.) O. Kuntze) in China. SCI REP-UK 6: 35287

Weir BS, Johnston PR, Damm U (2012) The Colletotrichum gloeosporioides species complex. Stud Mycol 73:115-180

White TJ, Bruns T, Lee S, Taylor J (1990) Amplification and direct sequencing of fungal ribosomal RNA genes for phylogenetics. In: Innis MA, Gelfand DH, Sninsky JJ, WhiteTJ (eds) PCR protocols, a guide to methods and applications. Academic Press, San Diego, pp 315-322

Yao YQ, Lan F, Qiao YM, Wei JG, Huang RS, Li LB (2017) Endophytic fungi harbored in the root of Sophora tonkinensis Gapnep: Diversity and biocontrol potential against phytopathogens. Microbiology Open 3:1-17. https://doi.org/10.1002/mbo3.347

Zhang YW, Long D, Wang JW, Li QQ, Wang ZW, Lin W, Yuan GQ (2020) Morphological and molecular identification of Colletotrichum siamense, a novel leaf pathogen associated with Sterculia lanceolata recorded in China. J Phytopathol 168:1-9. https://doi.org/10.1111/jph.12909

Zhang YW, Shen R, Mo YX, Li QQ, Lin W, Yuan GQ (2020) Colletotrichum siamense: A novel leaf pathogen of Sterculia nobilis Smith detected in China. Forest Pathol 50:1-8. https:// doi.org/10.1111/efp. 12575 